\title{
A NEW SPECIES OF THE GENUS GOBIO CUVIER, 1816 (ACTYNOPTERIGII, CYPRINIDAE) FROM THE IBERIAN PENINSULA AND SOUTHWESTERN FRANCE
}

\author{
I. Doadrio ${ }^{1}$ and M. J. Madeira ${ }^{2}$
}

\begin{abstract}
Iberian and southern French populations of the genus Gobio, considered in the past to be populations of Gobio gobio, are assigned to a new species (Gobio lozanoi n. sp.) based on genetic and morphological characters. This new species of the genus Gobio is found in the basins of the Rivers Adour in France and Bidasoa, Duero, Ebro, Guadalete, Guadiana, Guadalquivir, Júcar, Llobregat, Mondego, Mijares, Nalón, Nansa, Miño, Segura, Tajo, and Turia in the Iberian Peninsula. The new species is distinguished from Gobio gobio by a combination of the following characters: 36-39 scales on the lateral line, 3 scales below the lateral line. The distance between the pectoral and ventral fins is greater than that between the ventral and anal fins (VAL/PVL $\leq 0.8$ ). The preorbital distance is short and the head is wide $(\mathrm{ED} / \mathrm{PrOL} \geq 0.56 ; \mathrm{PrOL} / \mathrm{HH} \leq 0.69 ; \mathrm{PrOL} / \mathrm{HW} \leq 0.68)$. Divergence distances in cytochrome $b$ between Gobio gobio and the new species are " $p$ " $=4.8-5.9 \%$.
\end{abstract}

Key words: Cypriniformes, Cyprinidae, Taxonomy, Gobio gobio, Iberian Peninsula, South France.

\section{RESUMEN}

\section{Una nueva especie del género Gobio Cuvier, 1816 (Actinopterygii, Cyprinidae)} de la Península Ibérica y sur de Francia

Se describe una nueva especie del género Gobio de la Península Ibérica y sur de Francia (Gobio lozanoi n. sp.), considerada hasta ahora una población de Gobio gobio, en base a caracteres genéticos y morfológicos. La nueva especie del género Gobio procede de las cuencas de los ríos Adour en Francia y Bidasoa, Duero, Ebro, Guadalete, Guadiana, Guadalquivir, Júcar, Llobregat, Mondego, Mijares, Nalón, Nansa, Miño, Segura, Tajo y Turia en la Península Ibérica. Esta nueva especie se diferencia de Gobio gobio por una combinación de los siguientes caracteres: 36-39 escamas en la línea lateral, 3 escamas por debajo de la línea lateral. La distancia entre la aleta pectoral y ventral es siempre mayor que entre la aleta ventral y la anal (VAL/PVL $\leq 0.8$ ). La distancia preorbital es corta y la cabeza ancha $(\mathrm{ED} / \mathrm{PrOL} \geq 0.56 ; \operatorname{PrOL} / \mathrm{HH} \leq 0.69$; PrOL/HW $\leq 0.68$ ). Para el citocromo $b$ la divergencia entre Gobio gobio y la nueva especie fue de " $p "=4.8-5.9 \%$.

Palabras clave: Cypriniformes, Cyprinidae, Taxonomía, Gobio gobio, Península Ibérica, Sur de Francia.

Museo Nacional de Ciencias Naturales. José Gutiérrez Abascal 2.28006 Madrid. Spain. mcnd147@mncn.csic.es Dep. Zoología y Dinámica Celular Animal. Fac. Farmacia. Universidad del País Vasco (U.P.V). Paseo de la Universidad 7. 01006 (Vitoria-Gasteiz) Spain. zobmagam@vc.ehu.es 


\section{Introduction}

Gobio (Cuvier, 1816) is a genus of approximately 20 species distributed throughout Europe and Asia. Within this genus, Gobio gobio (Linnaeus, 1758 ) with its numerous described subspecies and local forms, is one of the most variable fish species in all of Europe owing to its phenotypic plasticity.

The common gudgeon (Gobio gobio) is a Palaearctic species whose distribution area extends throughout most of Europe, Anatolia, Siberia and Central Asia. In the Iberian Peninsula it was cited for the first time in Matosinho, Portugal (Osorio, 1896) and later in the Duero basin in Spain (Lozano-Rey, 1919). Its dispersal capacity and ability to colonize new areas favoured its rapid expansion throughout the entire geographical area of the Iberian Peninsula over the last decades. As a result, the common gudgeon was considered to be an introduced species in the Iberian Peninsula. Only one study, based on biometrical analyses, considered the allochthonous nature of gudgeon populations in the Iberian Peninsula (Coelho, 1981).

However, in the course of recent genetic studies of different species of the genus Gobio, using a mitochondrial DNA (cytochrome $b$ ) marker, the $G$. gobio populations from the Iberian Peninsula and southern France (Adour basin) were found to be genetically different from $G$. gobio populations in England and Central Europe (Madeira et al., in press). This last study confirms a phylogeographic genetic discontinuity between Iberian and other European populations. Thus, Iberian and Adour Basin G. gobio populations seem to have endemic origins. However, the majority of the endemic freshwater fishes of the Iberian Peninsula have narrower distributions ranges.

Gobio gobio populations from the Iberian Peninsula have a decidedly wider distribution range, and have been reported in all the main river basins of Spain (Doadrio \& Elvira, 1986) and Portugal (Almaça, 1965). This may be due to its use as live-bait in sport fishing and to having been translocated from basin to basin by human activity. As a consequence, there is low genetic variation between the populations from the Iberian Peninsula and southern France (Adour basin), making it difficult to determine in what basin the native populations originated.

The purpose of this study was describe the specimens from the Iberian Peninsula and Adour Basin as new species of the genus Gobio. Although this species had been defined through molecular analy- ses previously, it had not been named until this study was made.

\section{Material and Methods}

The description of this new Gobio species is based on the study of sixty-three adults from the Eresma River in Coca, Segovia. The holotype and a series of paratypes were deposited in Museo Nacional de Ciencias Naturales (Spain). For the morphometric analysis we studied the following Gobio gobio material: MNCN20568-20573, six individuals from Vltava River, Brno, Czech Republic. MNCN20698-20707, 10 individuals from Elbe River, Cernylev, Czech Republic. MNCN20588-20594, 7 individuals from Elbe River, Nova Ves, Czech Republic. 94253-94263, 11 individuals from Mures River Lunca-Bradului, Romania. MNCN94322-94335, 14 individuals from Mures River Brancovenesti (Romania). MNCN195547-195556, 10 individuals from Thames River, Lombard Road, England.

Twenty-five morphometric variables were measured. All measurements were in millimetres and were log-transformed for morphometric analysis.

The following abbreviations were used for morphometric and meristic characters: SL, standard length; HL, head length; HH, head height; HW, head width; PrOL, preorbital length; ED, eye diameter; ID, interorbital distance; PRDD, predorsal distance; PrPD, prepectoral distance, PrVD, preventral distance; PrAD, preanal distance; CPL, caudal peduncle length; APL, anal peduncle length; PVL, pectoral-ventral length; VAL, ventral-anal length; DFL, dorsal fin length; DFH, dorsal fin height; PFL, pectoral fin length; VFL, ventral fin length; AFL, anal fin length; AFH, anal fin height; CFL, caudal fin length, BD body depth; BLD, body least depth; BL, barbel length; D, dorsal fin rays; $A$, anal fin rays; $P$, fin rays; $V$, fin rays; $\mathrm{C}$, fin rays; LLS, lateral line scales; LTU, upper transversal scales; LTL, lower transversal scales; PT, pharyngeal teeth. Only branched fins rays were counted.

Differences in body shape between populations were analysed using Principal Component Analysis (PCA). The Shear method was used to correct size effects (SPCA) (Humphries et al., 1981) using the programme SHEAR PCA available from N. MacLeod Natural History Museum London (http//www.nhm.ac.uk/hosted_sites/paleonet/ftp/ftp.html).

Institutional acronyms: MNCN Museo Nacional de Ciencias Naturales. 


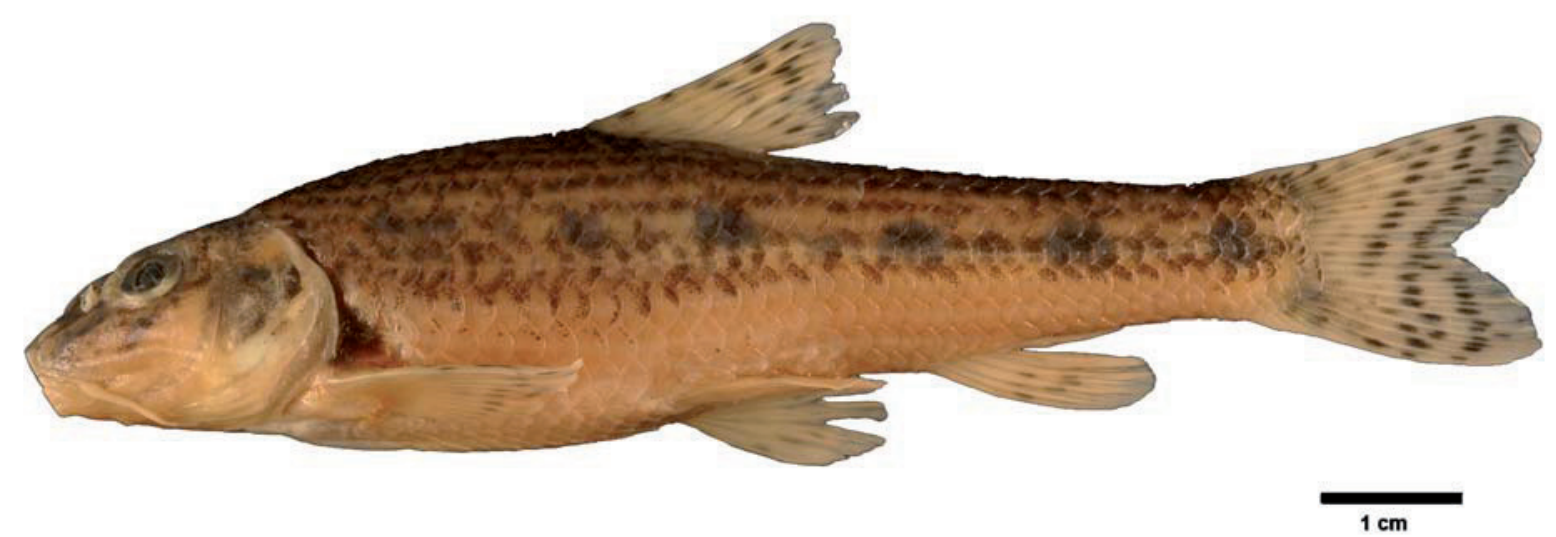

Fig. 1.-Gobio lozanoi sp. nov. Holotype MNCN153558; Eresma River, Duero Basin, Coca, Segovia. Spain. Scale = $10 \mathrm{~mm}$.

Fig. 1.- Gobio lozanoi sp. nov. Holotype MNCN153558; río Eresma, Cuenca del río Duero, Coca, Segovia. España. Escala = 10 $\mathrm{mm}$.

\section{Gobio lozanoi, new species}

(Fig. 1)

Holotype. MNCN153558, 88.2 mm SL; Eresma River, Duero Basin, Coca, Segovia. Spain. Leg J. Lobón, S. Torres and I. Doadrio. 14.VIII.1984 (Table 1).

PARATYPES. MNCN153557, 153559-153620. Eresma River, Duero Basin, Coca, Segovia. Spain. Leg J. Lobón, S. Torres and I. Doadrio. 14.VIII.1984.

Diagnosis. Differs from all other known species of Gobio by the following: 36-39 scales in the lateral line, 3 scales below the lateral line, distance between pectoral and ventral fin is greater than ventral anal distance (VAL/PVL $\leq 0.8$ ), the preorbital distance is short and the head is wide (ED/PrOL $\geq 0.56$, $\mathrm{PrOL} / \mathrm{HH} \leq 0.69$; PrOL/HW $\leq 0.68$ ). Divergence distances in cytochrome $b$ between G. gobio and the new species are " $p "=0.48-0.59$.

Description. D II-III 7, A II-III 6, P 14 (15), V II 6 (7), C, LLS 36-39 ( $\bar{x}=37.4)$, LTU 5-6 ( $x=$ 5.3), LTL 3, PT 5.3 (2)-5.3 (2), 18 (17) abdominal vertebrae, 17 caudal vertebrae. Morphometric characters are given in Tables 1 and 2. The body is elongated and moderately compressed. Maximum body depth is 4-5.2 (4.5) times the standard length. Minimum body depth is 3.7-5.2 (4.4) times the length of the dorsal caudal peduncle. The head is wider and shorter than that of G. gobio and is 3.8-4.3 (4) times the standard length. Preorbital distance short, 2.3-3 (2.5) times the head length;
1.4-1.8 (1.5) times the head height and 1.45-1.82 (1.61) the width head (Table 3a-c). The eye diameter length is 1.4-2.1 (1.8) times the preorbital distance. Ventral fin is inserted posteriorly to the origin of the dorsal fin, on the same axis (Table $3 \mathrm{~d})$. Predorsal length is $1-1.1$ (1.1) times the preventral length. Distance between pectoral and ventral fin is longer than ventral-anal distance. Pectoral-ventral distance is 1.1-1.5 (1.2) times ventral-anal distance. Fin size moderately large. There is a pair of maxillary barbels of variable size. All populations of this species except those from the Bidasoa River in the Iberian Peninsula and those from the Adour River in France have longer barbels than G. gobio. Barbels reach the posterior border of the eye. Scales larger than those of G. gobio and there are only 3 scales on the transversal rows under the lateral line.

Pigmentation Pattern. One row of 6-12 (7) dark blotches along the lateral line. Except in the ventral part of the body the scales are black remarked. Upper cephalic region darkly spotted. Below the eye there is a characteristic elongated black spot. The dorsal, caudal, pectoral and anal fins have a variable number of rows of dark spots. Above the lateral line the body is grey or brown while below it is light brown.

Etymology. The species is dedicated to Luis Lozano Rey (1878-1958) for his contribution to our knowledge of Iberian freshwater fishes. 
Table 1.- Statistical parameters for the morphometric and meristic characters of $G$. lozanoi sp. nov. type series. Variables are described in Methods. (SD = Standard deviation).

Tabla 1.- Parámetros estadísticos para los caracteres morfométricos y merísticos de la serie tipo de G. lozanoi sp. nov. Las variables se describen en la metodología. ( $\mathrm{SD}=$ desviación estandard).

\begin{tabular}{|c|c|c|c|c|}
\hline \multicolumn{5}{|c|}{ Gobio lozanoi nov. sp. } \\
\hline \multirow[t]{2}{*}{ Variable } & \multirow[t]{2}{*}{ Holotype } & \multicolumn{3}{|c|}{ Paratypes $(\mathrm{n}=62)$} \\
\hline & & Range & Mean & SD \\
\hline SL & 88.2 & $57.1-114.6$ & 88.1 & 10.6 \\
\hline HL & 22.8 & $15-28.3$ & 22.1 & 2.5 \\
\hline PrOL & 9.2 & $4.9-12.2$ & 8.9 & 1.3 \\
\hline ED & 4.9 & $3.3-6.2$ & 5 & 0.6 \\
\hline ID & 6.2 & $4.2-10.2$ & 6.5 & 1.1 \\
\hline HW & 14.3 & 8-18 & 14.2 & 1.9 \\
\hline $\mathrm{HH}$ & 15.5 & $8.5-17.7$ & 13.6 & 1.8 \\
\hline PrPD & 21.9 & $14.8-28.1$ & 22 & 2.7 \\
\hline PrVD & 44.8 & $30.2-56.2$ & 44.3 & 5.1 \\
\hline PRAD & 60.9 & $39.6-77.3$ & 61.8 & 7.5 \\
\hline PrDD & 41.0 & $26.4-54.2$ & 41.8 & 5 \\
\hline CPL & 39.3 & $23.1-46.6$ & 37.4 & 4.8 \\
\hline APL & 20.1 & $13.6-25.8$ & 19.7 & 2.3 \\
\hline PVL & 19.6 & $13 .-26.5$ & 19.9 & 2.4 \\
\hline VAL & 15.9 & $9.5-22.7$ & 16 & 2.4 \\
\hline DFL & 11.3 & $7.5-14.8$ & 11.5 & 1.6 \\
\hline DFH & 19.3 & $13.9-25$ & 18.9 & 2.1 \\
\hline PFL & 19.8 & $13-23$ & 18.9 & 2.2 \\
\hline VFL & 15.8 & $10.5-19.5$ & 15.7 & 1.7 \\
\hline AFL & 6.6 & $4.3-8.5$ & 6.6 & 0.9 \\
\hline $\mathrm{AFH}$ & 14.7 & $10-19.4$ & 14.5 & 1.9 \\
\hline CFL & 15.7 & $11.8-20.2$ & 16.6 & 1.8 \\
\hline $\mathrm{BD}$ & 21.2 & $12.2-26$ & 19.7 & 2.6 \\
\hline BLD & 8.5 & $5.4-11.3$ & 8.5 & 1.2 \\
\hline $\mathrm{BL}$ & 8.9 & $4.6-11.1$ & 8.6 & 1.2 \\
\hline LLS & 37 & $36-39$ & 37.4 & 0.8 \\
\hline LTU & 5 & $5-6$ & 5.3 & 0.4 \\
\hline LTL & 3 & $3-3$ & 3 & 0 \\
\hline $\mathrm{D}$ & 7 & 7.7 & 7 & 0 \\
\hline A & 6 & $6-6$ & 6 & 0 \\
\hline
\end{tabular}

DisTRIBUTION. Currently G. lozanoi is present in the Iberian Peninsula and in southern France in the basins of the Rivers Adour, Bidasoa, Duero, Mondego, Ebro, Guadalete, Guadiana, Guadalquivir, Júcar, Llobregat, Mijares, Nalón, Nansa, Miño, Segura, Tajo and Turia (Fig. 2). For many years, authors have considered Iberian populations of the
Table 2.- Statistical parameters for the morphometric characters of $G$. lozanoi sp. nov. Each variable is divided by standard length. Variables are described in Methods. $(\mathrm{SD}=$ Standard deviation).

Tabla 2.- Parámetros estadísticos para los caracteres morfométricos de G. lozanoi sp. nov. Cada variable está dividida por la longitud estandar. Las variables se describen en la metodología. $(\mathrm{SD}=$ desviación estandard $)$.

\begin{tabular}{lccc}
\hline & Gobio lozanoi nov. sp. $(\mathbf{n}=\mathbf{6 3})$ & \\
\hline Variable & Mean & Range & SD \\
\hline $\mathrm{SL}$ & 88.07 & $57.10-114.6$ & 11.41 \\
$\mathrm{HL} / \mathrm{SL}$ & 0.25 & $0.23-0.26$ & 0.01 \\
$\mathrm{PrOL} / \mathrm{SL}$ & 0.10 & $0.09-0.11$ & 0.01 \\
$\mathrm{ED} / \mathrm{SL}$ & 0.06 & $0.05-0.07$ & 0.00 \\
$\mathrm{ID} / \mathrm{SL}$ & 0.07 & $0.06-0.09$ & 0.01 \\
$\mathrm{HW} / \mathrm{SL}$ & 0.16 & $0.14-0.18$ & 0.01 \\
$\mathrm{HH} / \mathrm{SL}$ & 0.15 & $0.14-0.18$ & 0.01 \\
$\mathrm{PrPD} / \mathrm{SL}$ & 0.25 & $0.23-0.27$ & 0.01 \\
$\mathrm{PrVD} / \mathrm{SL}$ & 0.50 & $0.47-0.53$ & 0.01 \\
$\mathrm{PRAD} / \mathrm{SL}$ & 0.70 & $0.66-0.73$ & 0.01 \\
$\mathrm{PrDD} / \mathrm{SL}$ & 0.47 & $0.45-0.5$ & 0.01 \\
$\mathrm{CPL} / \mathrm{SL}$ & 0.42 & $0.39-0.46$ & 0.02 \\
$\mathrm{APL} / \mathrm{SL}$ & 0.22 & $0.19-0.24$ & 0.01 \\
$\mathrm{PVL} / \mathrm{SL}$ & 0.23 & $0.21-0.25$ & 0.01 \\
$\mathrm{VAL} / \mathrm{SL}$ & 0.18 & $0.16-0.21$ & 0.01 \\
$\mathrm{DFL} / \mathrm{SL}$ & 0.13 & $0.11-0.15$ & 0.01 \\
$\mathrm{DFH} / \mathrm{SL}$ & 0.22 & $0.19-0.24$ & 0.01 \\
$\mathrm{PFL} / \mathrm{SL}$ & 0.22 & $0.19-0.25$ & 0.01 \\
$\mathrm{VFL} / \mathrm{SL}$ & 0.18 & $0.16-0.2$ & 0.01 \\
$\mathrm{AFL} / \mathrm{SL}$ & 0.07 & $0.06-0.09$ & 0.01 \\
$\mathrm{AFH} / \mathrm{SL}$ & 0.16 & $0.14-0.19$ & 0.01 \\
$\mathrm{CFL} / \mathrm{SL}$ & 0.19 & $0.16-0.21$ & 0.01 \\
$\mathrm{BD} / \mathrm{SL}$ & 0.22 & $0.19-0.25$ & 0.01 \\
$\mathrm{BLD} / \mathrm{SL}$ & 0.10 & $0.08-0.11$ & 0.01 \\
$\mathrm{BL} / \mathrm{SL}$ & 0.10 & $0.08-0.12$ & 0.01 \\
\hline
\end{tabular}

genus Gobio to be allochthonous (Lozano-Rey, 1935, Coelho, 1981, Lobón-Cerviá \& Torres, 1984, Doadrio \& Elvira 1986, Lobón-Cerviá et al., 1991). The absence of reliable mentions prior to 1913 for Iberian G. gobio (Lozano Rey, 1919), a fact that is truly unusual considering that today it is one of the most abundant species in the Iberian Peninsula, gives credence to an allocthonous origin.

The first reference to the genus Gobio in the Iberian Peninsula is from Matosinho, a village located on the Atlantic coast near the estuary of the Duero River in Portugal (Osorio, 1896). Today, the 
Fig. 2.- Distribution range of G. lozanoi sp. nov.

Fig. 2.- Área de distribución de G. lozanoi sp. nov.

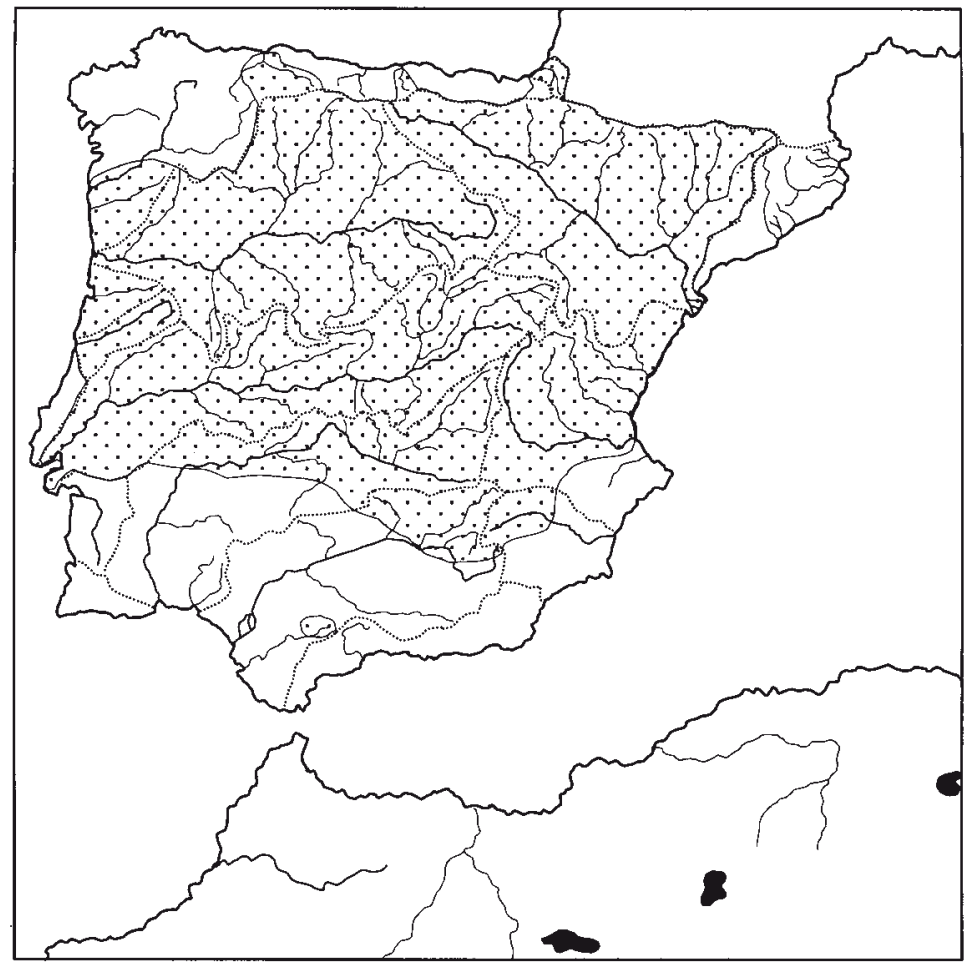

Table 3.- Frequency distribution of preorbital indexes: A) PrOL/ED; B) PrOL/HH; C) PrOL/HW and ventral index: D) VAL/PVL in G. gobio and G. lozanoi sp. nov.

Tabla 3.- Distribución de frecuencias de los índices preorbitales: A) PrOL/ED; B) PrOL/HH; C) PrOL/HW e índice ventral: D) VAL/PVL en G. gobio y G. lozanoi sp. nov.

\begin{tabular}{|c|c|c|c|c|c|c|c|c|}
\hline \multicolumn{9}{|l|}{ A) $\mathrm{PrOL} / \mathrm{ED}$} \\
\hline Species & $0.3-0.40$ & $0.41-0.50$ & $0.51-0.60$ & $0.61-0.70$ & $0.70-0.80$ & & & \\
\hline Gobio lozanoi $n . s p$. & 0 & 5 & 48 & 8 & 2 & & & \\
\hline Gobio gobio & 26 & 32 & & & & & & \\
\hline \multicolumn{9}{|l|}{ B) $\mathrm{PrOL} / \mathrm{HH}$} \\
\hline Species & $0.51-0.60$ & $0.61-0.70$ & $0.71-0.80$ & $0.81-0.90$ & $0.91-1$ & & & \\
\hline Gobio lozanoi $n$. sp. & 7 & 56 & 0 & 0 & & & & \\
\hline Gobio gobio & 0 & 0 & 33 & 22 & 3 & & & \\
\hline \multicolumn{9}{|l|}{ C) $\mathrm{PrOL} / \mathrm{HW}$} \\
\hline $\begin{array}{l}\text { Species } \\
\end{array}$ & $0.55-0.60$ & $0.61-0.65$ & $0.66-0.70$ & 0.71-0.75 & $0.76-0.80$ & $0.81-0.85$ & $0.86-0.9$ & \\
\hline Gobio lozanoi $n$. sp. & 18 & 29 & 16 & 0 & & & & \\
\hline Gobio gobio & 0 & 0 & 2 & 25 & 16 & 6 & 3 & \\
\hline \multicolumn{9}{|l|}{ D) VAL/PVL } \\
\hline Species & $0.70-0.75$ & $0.76-0.8$ & $0.81-0.85$ & $0.86-0.90$ & $0.91-0.95$ & $0.96-1$ & $1.05-1.1$ & 1.11-1.15 \\
\hline Gobio lozanoi $n$. $s p$. & 12 & 17 & 22 & 12 & 0 & 0 & 0 & \\
\hline Gobio gobio & 0 & 0 & 0 & 0 & 13 & 17 & 13 & 2 \\
\hline
\end{tabular}




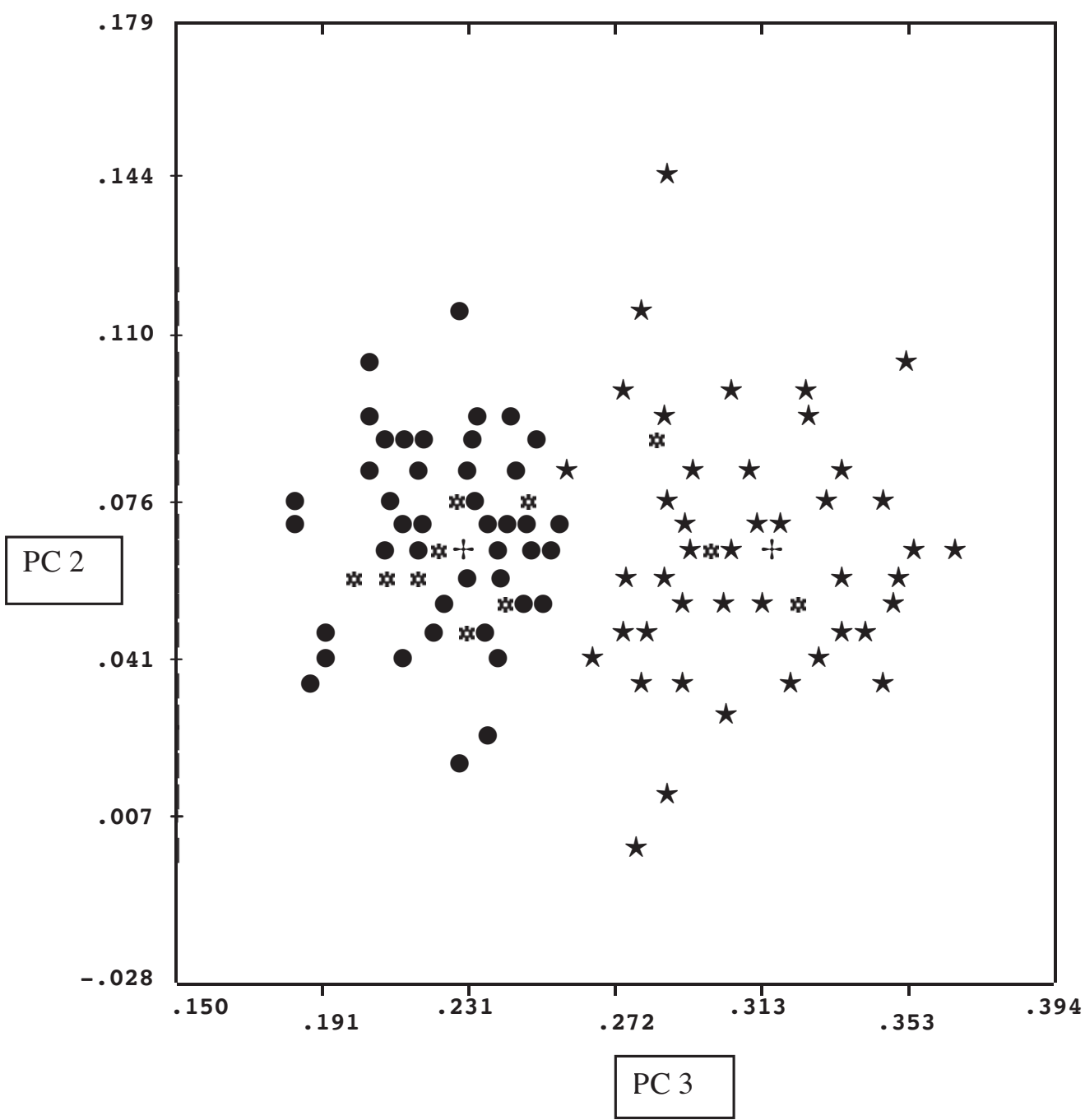

Fig. 3.- Bivariate Plot of Principal Components 2 VS. Principal Components 3 for 24 Shear corrected variables. Gobio lozanoi $(\mathrm{n}=63)$. Gobio gobio $(\mathrm{n}=58)$.

Fig. 3.- Gráfico bivariante del segundo componente principal frente al tercero para 24 variables corregidas mediante Shear. Gobio lozanoi $(\mathrm{n}=63)$. $\star$ Gobio gobio $(\mathrm{n}=58)$. $\mathbf{\psi}=$ Localizaciones individuales múltiples $+=$ Centroide.

species is not found in Matosinho nor is there an appropriate habitat for the genus Gobio in this region. It is likely, therefore, that Osorio's (1896) original citation refers to the genus Gobius; a genus that is often found in estuaries and marine environments. The first reliable locality reference for the genus Gobio is the Voltoya River, in the Duero basin, from which individuals were deposited in the MNCN in 1913 (Lozano-Rey, 1919, Doadrio, 1989).

Just within the last years Doadrio (2001) has proposed an autochthonous origin for some of the
Iberian populations located in the Bidasoa and Ebro Rivers. Recently, molecular analysis has revealed that Iberian and French populations from various drainages are autochthonous and originated from a limited area of the Iberian Peninsula or south of France (Madeira et al., in press).

Further genetic variability studies carried out in the different basins could resolve the question of where exactly in the Iberian Peninsula and southern France the species originated. 
Table 4.- Eigenvectors for the first three principal components shear transformed for 24 variables.

Tabla 4.- Eigenvectors para los tres primeros componentes principales transformados por el método de Shear.

\begin{tabular}{lccc}
\hline Eigenvectors & I & II & III \\
\hline SL & 0.109849 & 0.059693 & 0.022847 \\
HL & 0.148667 & 0.030301 & 0.025726 \\
PrOL & 0.150266 & 0.125809 & 0.032930 \\
ED & 0.222007 & 0.374092 & 0.052206 \\
HW & 0.393193 & $\mathbf{- 0 . 7 9 2 2 0 3}$ & -0.037895 \\
HH & 0.230504 & -0.014518 & 0.131641 \\
PrPD & 0.214581 & -0.043235 & -0.104643 \\
PrVD & 0.158466 & 0.122240 & 0.020712 \\
PRAD & 0.132064 & 0.050397 & 0.069842 \\
PrDD & 0.125980 & 0.056656 & 0.052370 \\
CPL & 0.133494 & 0.067586 & 0.002887 \\
APL & 0.133935 & 0.093201 & -0.009521 \\
PVL & 0.132788 & 0.197345 & 0.056381 \\
VAL & 0.186124 & -0.119967 & 0.116260 \\
DFL & 0.167926 & 0.215331 & 0.123474 \\
DFH & 0.225445 & 0.067765 & -0.230068 \\
PFL & 0.145541 & 0.026126 & -0.013758 \\
VFL & 0.151991 & 0.004140 & -0.058898 \\
AFL & 0.168052 & -0.071337 & -0.034807 \\
AFH & 0.296228 & 0.147692 & $\mathbf{- 0 . 7 4 4 6 5 6}$ \\
CFL & 0.177266 & 0.034647 & -0.033995 \\
BD & 0.203126 & -0.052513 & -0.037592 \\
BLD & 0.298598 & -0.144439 & 0.206496 \\
ID & 0.304277 & 0.120158 & 0.517391 \\
\hline & & &
\end{tabular}

Table 5.- Summary of diagnostic characters of G. lozanoi sp. nov.

Tabla 5.- Resumen de caracteres diagnósticos de G. lozanoi sp. nov.

\begin{tabular}{|c|c|c|}
\hline Characters & G. gobio $(\mathrm{n}=58)$ & G. lozanoi sp. nov. $(\mathrm{n}=63)$ \\
\hline Number of scales in the lateral line & $\bar{x}=41(39-43)$ & $\bar{x}=37.4(36-39)$ \\
\hline Number of scales below of the lateral line & 4 & 3 \\
\hline Preorbital index (PrOL/HH) & $0.5-0.7$ & $0.7-1$ \\
\hline \multicolumn{3}{|l|}{ Ventral Index } \\
\hline (VAL/PVL) & $0.7-0.9$ & $0.9-1.1$ \\
\hline Divergence to cytochrome $b$ gene sequences & & \\
\hline
\end{tabular}

Common names. Gobio, Cabezudo, Gobi, Gobioa.

REMARKS. The species inhabits very different kind of habitats. In northern Spain, southern France and the Duero basin it characteristically inhabits streams and rivers with clear water, gravel or sandy bottoms. In the central Iberian Peninsula this species also lives in lowland waters that are characteristically slow moving with gravel, sandy and clayey bottoms. The spawning period is longer in $G$. lozanoi populations than in G. gobio (LobónCerviá \& Torres, 1984). In the Lozoya River, spawning occurrs from mid May and early June to the end of July or early August (Lobón-Cerviá \& Torres, 1984) and from June to August in the Nivelle River (Bernet, 1960). The life span of $G$. lozanoi is short; reproduction is early (1-year-old) and tends to be semelparous (Lobón-Cerviá et al., 1991). Populations of $G$. lozanoi are highly abundant, and in the Ucero River (Duero basin) densities of 1047 individuals per hectare have been reported (Lobón-Cerviá et al., 1986)

\section{Discussion}

Populations from the Iberian Peninsula and Adour River in France are so highly divergent from other populations of $G$. gobio, both morphologically and genetically (Table 5), that separating them into distinct species is warranted. No existing name can be assigned to them; so therefore, we have chosen to call this population Gobio lozanoi sp. nov.

Gobio lozanoi is differentiated from other populations of $G$. gobio by: 1) its much shorter snout 


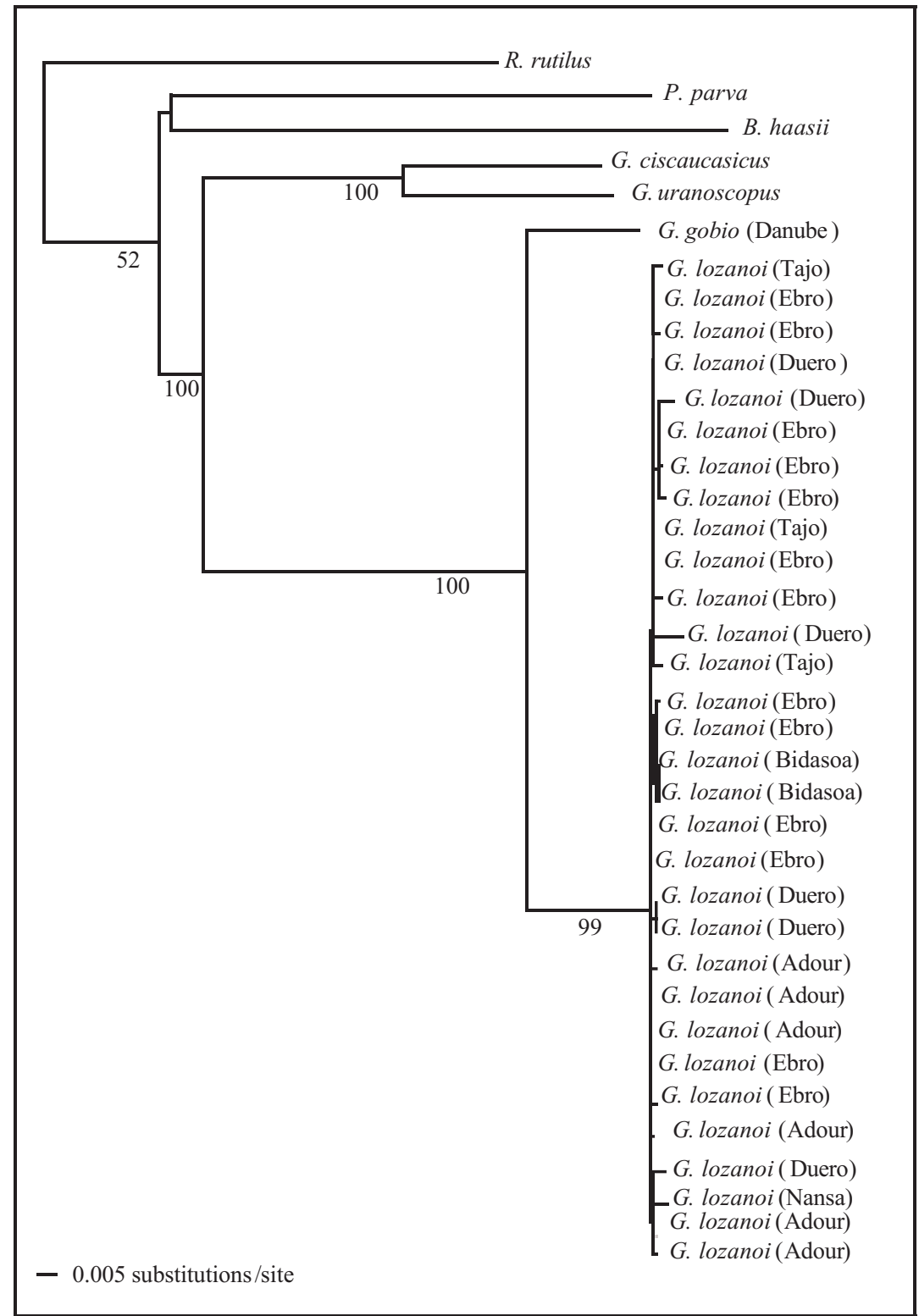

Fig. 4.- Phylogenetic tree of 35 analysed specimens of the genus Gobio recovered from cytochrome $b$ sequences according to the neighbour-joinig method based on the best model of evolution that fit our data using the program Model test 3.04 (Posada \& Crandall, 1998). Branch lengths are proportional to the estimated mean number of substitutions per site (see scale bar) (from Madeira et al., in press). The Ibero-French populations are here described as G. lozanoi $n$. sp. Numbers are bootstrap values for 500 replicates.

Fig. 4.- Árbol filogenético para 35 individuos del género Gobio basado en secuencias de citocromo $b$ y realizadas con el método de "neighbour-joinig" basado en el mejor modelo evolutivo que se ajustó a nuestros datos usando el programa Model test 3.04 (Posada \& Crandall, 1998). La longitud de las ramas es proporcional al número medio de sustituciones por sitio (ver escala) (tomado de Madeira et al., in press). Las poblaciones ibero-francesas son descritas aqui como G. lozanoi $n$. sp. Números son valores de Bootstrap para 500 réplicas. 
and wide head 2) fewer scales on and below the lateral line 3) greater length distance between pectoral and ventral fins than between ventral-anal.

A PCA analysis with 24 Shear morphometric corrected variables was carried out to remove size effect. The barbels length was removed because of the high variability found in this character in the Iberian populations. The area of the scores of each component differed significantly (MANOVA) between G. gobio and G. lozanoi for the first three components. Significant differences in morphology were found between G. lozanoi and G. gobio principally as a result of the contribution of the second size corrected component (Fig. 3). The highest eigenvector for the second component was the wide head (Table 4).

The Gobio gobio with the least number of scales on the lateral line ( $\bar{x}=37.5$ 36-39) (Banarescu et al., 1999) are found in populations from Skadar lake $(\bar{x}=38.5$ 33-41; Ivanovic, 1973$)$ and the Po River ( $\bar{x}=38.4$ 37-40; Bianco \& Tabborelli, 1984 Notwithstanding, we found that G. gobio always has a greater number of scales on the lateral line than does G. lozanoi. Three scales on the lower row of the lateral line have been found before in Iberian populations (Coelho, 1981) but not in other European populations (Banarescu et al., 1999). Head and preorbital lengths reported in the literature for G. gobio populations are always greater than those reported for G. lozanoi. Only some populations of G. gobio lepidolaemus and G. gobio kovatchevi have similar values to G. lozanoi (Banarescu et al., 1999).

Within of genus Gobio the sister species of Gobio lozanoi is G. gobio (fig. 4) other european species of this genus are very different morphologically and belong to the subgenera Romanogobio or Rheogobio (Banarescu et al., 1999). The genetic differentiation between $G$. gobio and G. lozanoi was " $p "=4.8-5.9 \%$; (Madeira et al. in press) a divergence similar to that found between other Iberian species of the genera Barbus (Doadrio et al., 2002), Chondrostoma (Doadrio and Carmona, in press) and Squalius (Sanjur et al., 2003).

\section{AKNOWLEDGEMENTS}

This study was financed by the DGES project REM20010662/G10. We thank J. Cubo, I. P. Garzón, J. A. GonzálezCarmona and A. Perdices for their assistance with field collections. We are grateful to the Basque Country Goverment who supported the initial project about the species Gobio gobio in the Bidasoa basin and to the people who helped us with fish collection for the initial study: R. Asensio, I. Urrizalki, E.
Beall, C. García de Leaniz, J. Álvarez and the Guard Services of the Navarra and Gipuzkoa local governments. Last, we are grateful to A. Machordom, B. Gómez-Moliner and R. Zardoya for their suggestions and improving some of the English text. James Watkins further revised the English text.

\section{References}

AlmaÇA, C., 1965. Contribution à la connaissance des poissons des eaux intérieures du Portugal. Revista da Facultade Ciências. Lisboa. $2^{a}$ serie, 13(2): 225-262.

Banarescu, P., Soric, M. V. \& ECONOMidis, P. S., 1999. Gobio gobio (Linnaeus, 1758). In: P. Banarescu (ed.). The Freshwater fishes of Europe, vol. 5(I). Aula Verlag. Wiesbaden: 78-134.

BERNET, B., 1960. Recherches biologiques sur les populations de Gobio gobio (Linné, 1758) de la Nivelle, fleuve cotier du Pays Basque. Annales de la Station Centrale d'Hydrobiologie Appliquée, 8: 127-180.

Bianco, P. G. \& Taraborelli, T., 1984. Gobio gobio benacensis (Pollini, 1816) sottoespecie valida per l'Italia (Pisces, Cyprinidae). Bolletino Museo Civico di Storia Naturale Verona, 11: 525-536.

Coelho, M. M., 1981. Contributions to the knowledge of the populations of Gobio gobio (Linnaeus, 1758) (Pisces, Cyprinidae) in Portugal. Arquivos do Museo Bocage, 1(5): 67-94.

DoAdrio, I., 1989. Catálogo de los peces de agua dulce del Museo Nacional de Ciencias Naturales. MNCNCSIC. Madrid. 185 pp.

DOADRIO, I., 2001. Atlas y libro rojo de la ictiofauna continental española. MIMAM-CSIC. Madrid. 363 pp.

DoAdrio, I. \& CARMONA, J. A. (In press). Phylogenetic relationships of the genus Chondrostoma (Actynopterygii, Cyprinidae) using cytochrome $b$ sequences Molecular Phylogenetics and Evolution.

DoAdrio, I. CARmona, J. A. \& Machordom, A., 2002. Haplotype diversity and phylogenetic relationships among the Iberian Barbels (Barbus, Cyprinidae) reveal two evolutionary lineages. The Journal of Heredity, 93(2): 140-147.

DoAdrio, I. \& ElvirA, B., 1986. Sobre la distribución de Gobio gobio (L., 1758) (Ostariophysi, Cyprinidae) en España. Doñana Acta Vertebrata, 13: 165-166.

Humphries, J. M., Bookstein, F. L., Chernoff, C., Smith, G. R., EldER, R. L. \& Poss, S. G., 1981. Multivariate discrimination by shape in relation to size. Systematic Zoology, 30: 291-308.

IvANOVIC, B. M., 1973. Ichthyofauna of Skadar Lake. Biological Station. Titograd. $146 \mathrm{pp}$.

Lobón-Cerviá, J., de SostoA, A. \& Montañés, C., 1986. Fish production and its relation with the community structure in an aquifer-fed stream of old Castile (Spain). Polskie Archiwum für Hydrobiologii, 33(3/4): 333-343. 
Lobón-Cerviá, J., Montañés, C. \& DE SostoA, A., 1991. Influence of environment upon the life history of gudgeon Gobio gobio (L.): a recent and successful colonizer of the Iberian Peninsula. Journal of Fish Biology, 39: 285-300.

LobÓn-CERviÁ, J. \& Torres, S., 1984. On the growth and reproduction of two populations of gudgeon (Gobio gobio L.) in Central Spain. Acta Hydrobiologica, 25/26(1): 101-115.

LoZANO-Rey, L., 1919. Los peces de la fauna ibérica en la colección del Museo el 1 de enero de 1919. Trabajos del Museo Nacional de Ciencias Naturales. Madrid (serie Zool). 39: 1-112.

LoZANO-REy, L., 1935. Los peces fluviales de España. Memorias de la Real Academia de Ciencias Exactas, Físicas y Naturales, 5: 1-390

Madeira, M. J., Gómez-Moliner, B. J. \& DoAdrio, I. (In press). Genetic characterization of Gobio gobio populations of the Iberian Peninsula based on cytochrome $b$ sequences. Folia Zoologica.
PosadA, D. \& CRANDAll, K. A., 1998. Modeltest: testing the model of DNA substitution. Bioinformatics, 14: $817-818$

Osorio, B., 1896. Peixes de Matosinhos (Terceiro appendice ao catalogo dos peixes de portugal de Felix Capello. Jornal de Sciencias Mathematicas, Physicas e Naturaes 2a serie, 15: 131-159.

Sanjur, O. I., Carmona, J. A. \& Doadrio, I. 2003. Evolutionary and biogeographical patterns within Iberian populations of the genus Squalius inferred from molecular data. Molecular Phylogenetics and Evolution, 29: 20-30. 